\title{
Kualitas Karkas serta Uji Organoleptik Ayam Peraskok, Ayam Buras Kampung, dan Ayam Broiler pada Umur Potong Belah Empat
}

Carcass quality and organoleptic of peraskok, native chickens, and broiler to provide four-cut chicken

Kususiyah

Jurusan Peternakan, Fakultas Pertanian Universitas Bengkulu Jalan Raya Kandang Limun, Bengkulu. Telp.(0736) 2170 pst.219.

\section{ABSTRACT}

Peraskok is a cross between layer and Bangkok native chicken which are expected to have high growth rate and native chicken quality. An experiment was conducted to evaluate carcass quality and organoleptic of Peraskok (a cross between layer chicken and Bangkok native chicken), native chickens and broiler to provide fourcut chickens. Five chicken, each for peraskok, native chickens and broiler were sampled for evaluation of chicken weight at four-cut age, carcass weight, carcass percentage, shank length, drumstick length, back length, carcass appearance, and carcass-preference tests, including taste, smell, color, and texture. Data were tabulated and discussed descriptively. The results demonstrated that carcass quality of peraskok was similar to those of native chicken.

Keyword: native chicken, carcass, organoleptic

\begin{abstract}
ABSTRAK
Peraskok merupakan ayam F1 hasil persilangan ayam ras petelur dengan ayam Buras Bangkok yang diharapkan memiliki pertumbuhan cepat dan kualitas daging setara dengan ayam kampung.Penelitian ini bertujuan untuk mengevaluasi kualitas serta uji organoleptik Ayam Peraskok, Ayam Buras Kampung, dan Ayam Broiler pada umur potong belah empat. Lima ekor Ayam Peraskok, lima ekor Ayam Buras Kampung, lima ekor Ayam Broiler dipergunakan untuk pengambilan data. Peubah yang diukur adalah berat potong belah empat, berat karkas, persentase karkas, panjang shank, panjang drumstik, panjang punggung, tampilan karkas, dan uji organoleptik yang meliputi : uji rasa, uji bau, uji warna, serta kekesatan karkas. Data yang diperoleh ditabulasi dan dibahas secara deskriptif. Hasil penelitian menunjukkan bahwa kualitas karkas Ayam Peraskok sama dengan kualitas karkas Ayam Kampung.
\end{abstract}

Kata kunci: ayam kampung, karkas, organoleptik 


\section{PENDAHULUAN}

Istilah ayam potong belah empat telah dikenal oleh masyarakat. Biasanya ayam potong belah empat ini diolah sebagai ayam bakar atau gulai ayam. Pada awalnya jenis ayam yang digunakan sebagai ayam potong belah empat ini adalah ayam buras, namun saat ini ayam ras pedaging (broiler) juga telah diusahakan sebagai ayam potong belah empat. Munculnya ayam potong belah empat dari broiler ini karena ketersediaan bibit broiler dan cepatnya pertumbuhan ayam broiler itu sendiri, sementara potensi genetik ayam buras yg relatif rendah (Rasyaf, 1995, Kingston, 1979) menyebabkan perkembangan dan pertumbuhan ayam buras tergolong lambat. Untuk mengatasi lambatnya perkembangan dan pertumbuhan ayam buras ini perlu dilakukan persilangan. Melalui persilangan, menurut Sheridan (1986) dan Warwick et al. (1990), efek komplementer dari persilangan akan meningkatkan produktivitas ternak. Ayam Peraskok adalah ayam hasil persilangan antara ayam ras petelur betina dengan ayam buras jantan jenis bangkok (Kususiyah, 2010). Postur tubuh ayam buras bangkok dengan perdagingan yang baik ini bila disilangkan dengan ayam ras petelur disinyalir akan menghasilkan keturunan yang mirip dengan ayam buras dengan pertumbuhan yang lebih baik tanpa mengurangi cita rasanya sebagaimana ayam buras.
Penelitian ini bertujuan untuk mengevaluasi kualitas karkas serta uji organoleptik Ayam Peraskok, Ayam Buras, dan Ayam Broiler pada umur potong belah empat.

\section{METODE PENELITIAN}

Penelitian ini menggunakan 15 ekor ayam; yang terdiri dari 5 ekor Ayam Buras, 5 ekor Ayam Peraskok, dan 5 ekor Ayam Ras pedaging (broiler). Ayam yang digunakan adalah ayam pada umur potong belah empat yaitu Ayam Peraskok berumur 10 minggu dengan berat hidup sekitar 700 g, Ayam Buras berumur 12 minggu dengan berat hidup sekitar 700 g, dan Ayam Ras pedaging berumur 4 minggu dengan berat hidup sekitar 1000 g. Semua ayam dipotong, dibului, dipotong kaki dan lehernya, dikeluarkan isi jeroannya, lalu diambil datanya. Data yang diperoleh ditabulasi dan dibahas secara deskriptif. Parameter yang diukur meliputi :

1. Persentase karkas, diketahui dengan cara membandingkan berat karkas dan berat hidup dikali $100 \%$

2. Uji rasa, penilaian dilakukan oleh panelis dengan memberi skor sebagai berikut : skor 1 sangat tidak enak, skor 2 tidak enak, skor 3 kurang enak, skor 4 enak, dan skor 5 sangat enak

3. Warna karkas, penilaian dilakukan oleh panelis uji rasa dengan 
memberi skor sebagai berikut : skor 1sangat tidak suka, skor 2 tidak suka, skor 3 kurang suka, skor 4 suka, dan skor 5 sangat suka

4. Tampilan karkas, penilaian dilakukan oleh panelis uji rasa dengan menjawab pertanyaan: jenis ayam apa dari karkas ayam yang disajikan, skor 1 adalah ayam ras pedaging, skor 2 adalah ayam buras atau ayam kampung

5. Panjang shank, diukur panjang bagian shanknya

6. Panjang drumnstick, diketahui dengan mengukur panjang drumsticknya

7. Panjang punggung, diketahui dengan mengukur bagian punggung mulai dari pangkal leher sampai pangkal pigostile (tunggir).

8. Kekesatan karkas, diukur dengan mengamati karkas sambil menekan karkas untuk diketahui kekesatannya dengan memberi skor sebagai berikut : skor 1 sangat lembek; skor 2 lembek; skor 3 agak lembek; skor 4 tidak lembek; skor 5 pemilihan panelis dengan kriteria penggemar ayam kampung ini diharapkan agar panelis lebih jeli dalam menilai karkas yang disajikan.

\section{HASIL DAN PEMBAHASAN}

Rataan berat hidup, berat karkas dan persentase karkas ayam buras, ayam peraskok dan ayam broiler pada umur potong belah empat disajikan pada Tabel 1. Pada umumnya ayam potong belah empat dari ayam buras dipotong pada berat badan sekitar 700 gram, sedangkan ayam potong belah empat dari ayam broiler dipotong saat umur 4 minggu.

Terlihat dari Tabel 1. bahwa untuk mencapai berat potong belah empat, umur yang dicapai dari masing-masing jenis ayam berbedabeda. Ayam broiler yang merupakan ayam pedaging, pada umur 4 minggu telah mencapai berat 1014 g per ekor, Ayam Peraskok yg merupakan hasil

persilangan antara ayam ras petelur dengan Ayam Buras Bangkok pada

Tabel 1. Rataan berat hidup, berat karkas, dan persentase berat karkas Ayam Buras, Ayam Peraskok dan Ayam Broiler pada umur potong belah empat

\begin{tabular}{lccc}
\hline Jenis ayam & Berat Hidup $(\mathrm{g})$ & Berat Karkas $(\mathrm{g})$ & Persentase Karkas (\%) \\
\hline Ayam Peraskok Umur 10 Mingu & 728 & 452 & 62,11 \\
Ayam Buras Umur 12 Minggu & 734 & 457 & 62,27 \\
Ayam Broiler Umur 4 Minggu & 1014 & 668 & 65,86 \\
\hline
\end{tabular}

kesat

Uji rasa, penilaian warna karkas, dan tampilan karkas dilakukan oleh panelis yang lebih menyukai ayam kampung dibanding ayam broiler, umur 10 minggu mencapai $728 \mathrm{~g}$ per ekor dan Ayam Buras Kampung pada umur 12 minggu mencapai berat $734 \mathrm{~g}$ per ekor. Hal ini menunjukkan bahwa untuk mencapai berat potong belah 
empat, Ayam Peraskok membutuhkan waktu pemeliharaan lebih cepat 2 minggu dibanding waktu yang dibutuhkan Ayam Buras, akan tetapi lebih lambat 6 minggu bila dibanding Ayam Broiler. Perbedaan capaian waktu ini disebabkan oleh perbedaan kemampuan jenis ayam rendah dibanding Ayam Broiler. Lebih rendahnya berat badan Ayam Peraskok dan Ayam Buras pada umur potong belah empat ini dapat dimengerti karena Ayam Broiler merupakan ayam pedaging sejati dengan efisiensi ransum lebih baik. Salah satu faktor yang menentukan

Tabel 2. Rataan panjang shank, panjang drumstik, dan panjang punggung, serta tampilan karkas pada umur potong belah empat

\begin{tabular}{lcccc}
\hline \multicolumn{1}{c}{ Jenis ayam } & $\begin{array}{c}\text { Panjang shank } \\
(\mathrm{cm})\end{array}$ & $\begin{array}{c}\text { Panjang } \\
\text { drumstik }(\mathrm{cm})\end{array}$ & $\begin{array}{c}\text { Panjang } \\
\text { Punggung }(\mathrm{cm})\end{array}$ & $\begin{array}{c}\text { Tampilan } \\
\text { Karkas }\end{array}$ \\
\hline $\begin{array}{l}\text { Ayam Peraskok } \\
\text { Umur 10 Mingu }\end{array}$ & 6.88 & 10.88 & 14.48 & 2 \\
$\begin{array}{l}\text { Ayam Buras Umur 12 } \\
\text { Minggu }\end{array}$ & 7.14 & 11.16 & 14.96 & 2 \\
$\begin{array}{l}\text { Ayam Broiler Umur 4 } \\
\text { Minggu }\end{array}$ & 5.1 & 8.2 & 14.1 & 1 \\
\hline
\end{tabular}

dalam mengkonsumsi ransum, selain itu juga disebabkan oleh perbedaan efisiensi penggunaan ransum. Kususiyah (2010) melaporkan bahwa konversi ransum Ayam Peraskok adalah 3.95 , sedangkan konversi ransum Ayam Buras Kampung sebesar 4.63. Konversi ransum pada broiler relatif lebih baik dibanding ayam peraskok maupun ayam buras kampung, yaitu 2,52 (Suteky et al., 2006) sedangkan menurut Brata (2009) berkisar 2,17-2,31.

\section{Berat Karkas dan Persentase Berat Karkas}

Sesuai capaian berat badan pada umur potong belah empat, berat karkas dan persentase karkas Ayam Peraskok dengan Ayam Buras tidak jauh berbeda, namun jauh lebih persentase karkas adalah berat badan ayam, dimana ayam dengan berat badan yang lebih tinggi mempunyai bagian terbuang yang lebih kecil dari pada yang memiliki berat badan yang lebih rendah (Rozany, 1981).

Rataan panjang shank, panjang drumstik, dan panjang punggung ditampilkan pada Tabel 2.

Ciri khas karkas ayam buras adalah berpenampilan langsing dengan pertulangan yang relatif panjang dibanding ayam broiler atau ayam pedaging. Tabel 2. memperlihatkan bahwa panjang shank, panjang drumstik dan panjang punggung Ayam Peraskok sedikit lebih pendek dibanding Ayam Buras Kampung, tetapi lebih panjang dibanding Ayam Broiler. Perbedaan panjang shank, panjang drumstik, dan 
panjang punggung antara Ayam Peraskok dengan Ayam Buras Kampung yang hanya sedikit ini secara visual tidak nampak sehingga telah membuat panelis tidak dapat membedakan dan menyatakan bahwa Ayam Peraskok adalah Ayam Buras Kampung. Hal ini ditunjukkan oleh penilaian dari semua panelis yang menyatakan bahwa tampilan karkas ayam peraskok dinilai 2 yang berarti sebagai karkas ayam kampung.

\section{Uji organoleptik}

Hasil penilaian panelis terhadap uji rasa menunjukkan bahwa skor uji rasa dari ketiga jenis ayam berada pada rasa enak dan sangat enak dengan skor rasa tertinggi pada Ayam Peraskok (4.75) diikuti Ayam Kampung (4.55) dan paling rendah skor rasa Ayam Broiler (4.45). Hal ini menunjukkan bahwa Ayam Peraskok dan Ayam Kampung lebih disukai dibanding Ayam Broiler. Selanjutnya skor uji bau karkas menunjukkan bahwa bau karkas Ayam Peraskok dan Ayam Kampung berada pada bau kurang amis dan tidak amis, sedangkan Ayam Broiler masuk katagori antara kurang amis dan agak amis. Skor uji bau karkas Ayam Peraskok adalah 4,75, skor uji bau karkas Ayam Buras adalah 4,65 sedangkan skor uji bau karkas Ayam Broiler paling rendah yaitu 3,33. Hal ini menunjukkan bahwa bau karkas Ayam Peraskok dan Ayam Kampung lebih disukai karena tidak lebih amis dibandingkan dengan bau karkas Ayam Broiler.

Hasil penilaian uji warna karkas menunjukkan bahwa skor uji warna karkas Ayam Peraskok adalah 5.0 tergolong warna kuning, sedangkan Ayam Buras Kampung adalah 4.75 tergolong antara warna kurang kuning sampai kuning, sementara itu skor warna karkas broiler adalah yang paling rendah yaitu 3.33 tergolong warna antara warna pucat dan tidak kuning. Hal ini menunjukkan bahwa warna karkas Ayam Peraskok dan Ayam Buras Kampung lebih kuning dibanding Ayam Broiler. Warna karkas kuning lebih disukai oleh kebanyakan konsumen sehingga ditemukan banyak pedagang Ayam Buras Kampung khususnya yang memanipulasi warna karkas ayam yang dijualnya dengan memberi pewarna kuning untuk menarik minat bagi konsumennya.

Hasil uji kekesatan karkas menunjukkan bahwa nilai kekesatan Ayam Peraskok sama dengan Ayam Kampung yaitu sebesar 4,7 tergolong antara tidak lembek dan kesat Sedangkan nilai kekesatan Ayam Broiler adalah sebesar 3,5 tergolong antara kurang lembek dan tidak lembek. Lebih tingginya nilai kekesatan Ayam Peraskok dan Ayam Kampung ini menunjukkan bahwa Ayam Peraskok dan Ayam Kampung lebih disukai dibanding karkas Ayam Broiler. 
ISSN 1978 - 3000

Tabel 3. Rataan skor uji rasa, bau karkas, warna karkas, tampilan karkas

\begin{tabular}{lcccc}
\hline \multicolumn{1}{c}{ Jenis ayam } & $\begin{array}{c}\text { Uji } \\
\text { Rasa }\end{array}$ & $\begin{array}{c}\text { Uji bau } \\
\text { karkas }\end{array}$ & $\begin{array}{c}\text { Uji warna } \\
\text { karkas }\end{array}$ & $\begin{array}{c}\text { Kekesatan } \\
\text { karkas }\end{array}$ \\
\hline $\begin{array}{l}\text { Ayam Peraskok Umur 10 } \\
\text { Minggu }\end{array}$ & 4.75 & 4.75 & 5.0 & 4.7 \\
Ayam Buras Umur 12 Minggu & 4.55 & 4.65 & & 4.7 \\
Ayam Broiler Umur 4 Minggu & 4.45 & 3.33 & 3.3 & 3.5 \\
\hline
\end{tabular}

\section{Keterangan:}

Uji rasa

: skor 1sangat tidak enak; skor 2 kurang enak; skor 3 agak enak; skor 4 enak; skor 5 sangat enak

Uji bau karkas : skor 1 sangat amis; skor 2 amis; skor 3 agak amis; skor 4 kurang amis; skor 5 tidak amis

Uji warna : skor 1 sangat pucat; skor 2 pucat; skor 3 tidak kuning; skor 4 kurang kuning; skor 5 kuning

Kekesatan karkas : skor 1 sangat lembek; skor 2 lembek; skor 3 agak lembek; skor 4 tidak lembek; skor 5 kesat

\section{SIMPULAN}

Kualitas karkas Ayam Peraskok sama dengan Ayam Buras Kampung.

\section{DAFTAR PUSTAKA}

Brata, B. 2009. Pengaruh pemberian isi rumen yang difermentasi dengan kapang trichoderma harzianum terhadap performans ayam broiler. 4(2) : 78-87

Kingston, D.J. 1979. Peranan ayam berkeliaran di Indonesia. Laporan Seminar Industri Perunggasan II. Balai Penelitian Ternak, Ciawi-Bogor.

Kususiyah. 2010. Performans Pertumbuhan Ayam Peraskok serta Income Over Feed and Chick Cost. Laporan Penelitian. Universitas Bengkulu.
Rasyaf, M. 1995. Beternak Ayam Petelur. Penebar Swadaya.

Rozany, H.R. 1981. Pengaruh minyak kelapa dan minyak kacang tanah terhadap pertumbuhan ayam pedaging.Tesis. Fakultas Pasca Sarjana. IPB.

Sheridan, A. K. 1986. Selection for heterosis from reciprocal cross population : Estimation of the F1 heterosis and its mode of inheritance. British Poultry Sci (27) $541-550$

Suteky, T., Y. Fenita, dan Yusnita. 2006. Suplementasi Enkapsulasi Minyak Ikan Lemuru (Sardinella longiceps) dalam Ransum terhadap performans ayam broiler. JSPI 1(1) : 1-7

Warwick, E. J., J. M. Astuti, dan W. Hardjosubroto. 1990. Pemuliaan Ternak. Gadjah Mada University Press. Yogyakarta. 